\title{
THE EFFECT OF ASSERTIVENESS TRAINING ON BULLYING IN JUNIOR HIGH SCHOOL
}

\author{
Hermalinda Herman, Deswita Nurshal, Dwi Novrianda
}

Maternal and Child Health Nursing, Faculty of Nursing Andalas University, Kampus Limau Manis Unand Padang, Pauh Distric Area, Padang, West Sumatera, Indonesia

\begin{abstract}
Bullying is a universal phenomenon and a common problem amongst school-aged children. Bullying can have a negative impact on the mental health and welfare of children. One strategy that can be done to prevent bullying is to practice assertiveness skills. This study aimed to identify the effect of assertiveness training in reducing bullying behaviour amongst students of Junior High School Padang. The study design was Quasi-experimental with a sample of 81 students (43 controls and 38 interventions). The intervention group received assertiveness training that consisted of 5 sessions, including communicating with others, declaring "no" to irrational requests, expressing complaints, rewarding others and accepting rewards and reinforcing the assertive behaviour with social-drama. Each session duration was 30-45 minutes. Adolescent Peer Relation Instrument (APRI) was applied to measure bullying behaviour. The statistical tests used were Wilcoxon and Mann Whitney. The results showed that there were differences in bullying behaviour before and after intervention between the control group and the intervention group ( $p$-value 0.001). It can be concluded that assertiveness skills training could be maintained as an intervention that would be able to prevent bullying in adolescents.
\end{abstract}

Key words: bullying, interpersonal relationship, reinforcement, adolescent, student

\section{ABSTRAK}

Bullying merupakan fenomena yang umum dan masalah yang universal pada anak usia sekolah. Bullying dapat menimbulkan efek negatif yang serius terhadap kesehatan mental dan kesejahteraan anak. Salah satu strategi yang dapat dilakukan untuk mencegah bullying adalah dengan latihan ketrampilan asertif. Penelitian ini bertujuan untuk mengidentifikasi pengaruh latihan asertif terhadap pencegahan bullying pada siswa SMP 28 Padang. Desain penelitian adalah Quasi eksperimen dengan jumlah sampel 81 sampel (43 kontrol dan 38 intervensi). Intervensi yang diberikan adalah latihan asertif training dengan 5 sesi selama 30-45 menit, yang terdiri dari berkomunikasi dengan orang lain, menyatakan "tidak" pada pernyataan yang tidak rasional, menyatakan keluhan, memberikan penghargaan kepada orang lain dan menerima pernghargaan serta mempertegas perilaku asertif dengan sosia drama. Adolescent Peer Relationship Instruments (APRI) digunakan untuk mengukur perilaku bullying. Uji statistik yang digunakan adalah Wilcoxon dan Mann Whitney. Hasil penelitian didapatkan bahwa terdapat perbedaan perilaku bullying sebelum dan sesudah intervensi antara kelompok kontrol dengan kelompok intervensi. Dapat disimpulkan bahwa latihan ketrampilan asertif dapat dipertimbangkan sebagai intervensi yang dapat mencegah perilaku bullying pada remaja.

Kata kunci: bullying, hubungan interpersonal, penghargaan, remaja, siswa 


\section{INTRODUCTION}

Bullying is a common phenomenon among school-aged children. In Canada, the prevalence of bullying behaviour among children has been found to be around $9 \%$ to $21 \%$. A study of children aged 12-17 years in five Asian countries (Cambodia, Indonesia, Nepal, Pakistan and Vietnam) showed that $71 \%$ of both boys/girls, had experienced violence from peers at school in the last six months (International Center for Research on Women, 2014). Research in Iceland found that $55 \%$ of students were victims of bullying behaviour 2 to 3 times per month (Garmy, Vilhjálmsson, \& Kristjánsdóttir, 2018). The average score of bullying behaviour was higher in boys. Research in Brazil indicates that the prevalence of bullying behaviour is high among Brazilian adolescents and boys are more likely to exhibit bullying behaviours (Pigozi \& Machado, 2015). However, in ClujNapoca, Romania, girls exhibited more bullying behaviour than boys (Beldeangalea, U, \& Igan, 2010).

Bullying is a complex social dynamic that can be understood from various theoretical frameworks. Social theory considers that bullying behaviour is used as a form of social protection in order to show strength and is perpetuated by the social environment. While the victims of bullying, feel that they can not escape from the bullies. The ambition to dominate is another factor for bullies which is used as a means to attain social and individual dominance (Evans \& Smokowski, 2016).

Bullying can have a serious negative effect on mental health and wellbeing (Tsitsika et al., 2014). Nurses, particularly those who work within schools, may become aware of the issue when they relate to perpetrators or victims who may experience depression, anxiety, substance abuse, poor social skills, low academic achievement and receive less attention from teachers. Children who are often bullied are at risk of suicide (Center for Disease Control and Prevention, 2014).

Some literature implies that psychoeducation and counseling groups are especially effective in lessening aggressiveness and bullying, both in schools and families (Horne, Stoddard, \&
Bell, 2007). A bullying prevention strategy can support children and teenagers to initiate and build positive relationships with others, prevent bullying behaviour and teach effective coping responses when being bullied. This strategy can be conducted in schools and within peer relationships (Pepler \& Craig, 2014).

Nevertheless, other studies suggest that school-based anti-bullying programs are not effective in decreasing bullying and violent behaviour in schools (Ferguson, San Miguel, Kilburn, \& Sanchez, 2007). However, interventions that focus on the entire school including staff have been found to be more effective in decreasing bullying than solely intervening through school curricula or social skills training (Cantone et al., 2015).

Bullying interventions may attempt to improve social skills in children and adolescents offering training in interpersonal skills, assertive coping strategies, empathy and conflict resolution (Pepler \& Craig, 2014). Assertiveness training raises an adolescents' awareness that they have the right to protect themselves from experiencing violence and intimidation.

Assertiveness training is effective in improving social coping skills in adolescents, whether they be bullies or victims of bullying, modifying aggressive behaviour, raising individual social skills and emotional health (Keliat, Tololiu, Daulima, \& Erawati, 2015). It can increase adolescents' knowledge, beliefs, selfconcept, self-efficacy and assertive behaviour, which helps change negative attitudes and create more effective interpersonal relationships (Boket, Bahrami, Kolyaie, \& Hosseini, 2015).

Assertiveness training programs reduce verbal violence among students and can be used as an effective intervention in violent behaviour (Boket et al., 2015). Groups who received assertive behaviour training significantly increased their knowledge about assertiveness and were able to behave assertively (Keliat et al., 2015).

Research conducted in Padang city in 2016 in junior high schools showed that $89.4 \%$ of students had bullied schoolmates either physically or verbally in 
the last six months. Further analysis showed a weak relationship between the school environment, the support of groups and teachers and bullying behaviours but there was no significant relationship between school pressure and bullying behaviour (Herman, Nurshal, \& Oktarina, 2017).

This study found that the highest prevalence of bullying occurred in Junior High School (SMP) 28 Padang and the study recommends further research into bullying prevention intervention through conducting assertiveness skills training. This research investigates the effect of such assertiveness training for students of SMP 28.

\section{METHOD \\ Study Design}

This study used a quasiexperimental design using pre and posttests with a control group to observe the effect of assertiveness skills training on reducing bullying behaviour in junior high school students in Padang city. This research involved two groups that are an intervention group given assertiveness skills training and a control group with no training.

\section{Setting and sample}

The research was conducted from May 2017 until December 2017 and focused on 757 students in SMP 28, Padang. Samples of 76 students were needed to include $10-20 \%$ of the total population (Sastroasmoro \& Ismail, 2010) but an extra $12.5 \%$ were added to anticipate the possibility of dropout so that the total initial sample size was 86 students; 43 in the intervention group and 43 in the control group.

Before selecting samples, researchers screened bullying behaviour for all students in SMP 28. Students who were identified as fulfilling the following inclusion criteria: 1) Children 12-18 years old, 2) Willing to be a respondent, 3) Be in the place at the time of research and 4) had demonstrated bullying behaviour (bullying behaviour score $\geq 18$ ) were identified and then samples were chosen from this using a simple random sampling technique.
At the time of the research, there were 5 respondents who dropped out of the intervention group because they did not complete the 5 sessions so therefore the intervention group contained only 38 students.

\section{Ethical considerations}

This study was approved by the Committee of the Research Ethics of the Faculty of Medicine, at the University of Andalas (approval no. 368/KEP/FK/2017). Before collecting the data, researchers gave an explanation to the respondents about the research procedure in which they were then asked to participate and also guaranteed anonymity.

\section{Measurements}

Data were collected using a questionnaire that was filled in by the students accompanied by the researchers to ensure students filled in the questionnaire correctly. The questionnaire consisted of two components: general and specific data. General data was demographic data and specific data was from an Indonesian translation of the bullying questionnaire Adolescent Peer Relations Instrument (Parada, 2000). The questionnaire contains two sections; section $A$ about bullying behaviour and section $B$ was about the experience of being bullied. Each section consisted of 18 statements with a choice of alternative answers: never happened; 1 , sometimes; 2 , once or twice a month; 3, once a week; 4 , more than once a week; 5 , and every day; 6 .

\section{Procedures \\ Pre-test}

Measure the bullying behaviour score before intervention.

\section{Intervention}

An assertiveness skills training session was given to the intervention group. Respondents were divided into groups of 4-6 students. Five 30-45 minute exercises related to communicating with others, saying "no" to irrational requests, expressing complaints, rewarding others and accepting awards, and reinforcement of assertive behaviour with social-drama 
were used. Methods used were lectures, group discussions, exercises and roleplaying. The researcher arranged a training module and diary of activities for students during the intervention which was carried out once. The control group followed the regular school program only.

\section{Post test}

The bullying behaviour score was remeasured after intervention.

\section{Data analysis}

The data that had been collected was edited, given an entry code, and incomplete data sets were discarded. Univariate analysis was conducted to describe the respondent demographics, characteristics and research variables using frequency distribution, mean, median, standard of deviation, minimum and maximum value. The data were analyzed using a Wilcoxon and Mann Whitney test.

\section{RESULT}

\section{Characteristics of respondents}

Table 1 provides information on gender, age, position in family and the number of siblings. More than half of the respondents were female, both in the intervention group and in the control group. The majority were 13 years old $(63.2 \%$ in the intervention group and $55.8 \%$ in the control group). More than half were second to fourth in the family $(63.2 \%$ and $60.5 \%$ respectively) and came from families of 2 to 4 children $(74.4 \%$ in the control group compared to $68.4 \%$ in the intervention group).

Table 1. Characteristics of students

\begin{tabular}{|c|c|c|c|c|c|}
\hline \multirow[t]{2}{*}{ No } & \multirow[t]{2}{*}{ Variable } & \multicolumn{2}{|c|}{$\begin{array}{l}\text { Intervention group } \\
(\mathrm{n}=38)\end{array}$} & \multicolumn{2}{|c|}{$\begin{array}{c}\text { Control group } \\
(n=43)\end{array}$} \\
\hline & & $n$ & $\%$ & $\mathbf{n}$ & $\%$ \\
\hline \multirow[t]{3}{*}{1.} & Gender & & & & \\
\hline & Female & 21 & 55.3 & 22 & 51.2 \\
\hline & Male & 17 & 44.7 & 21 & 48.8 \\
\hline \multicolumn{6}{|c|}{ 2. Age } \\
\hline & 12 years old & 1 & 2.6 & 3 & 7.0 \\
\hline & 13 years old & 12 & 63.2 & 24 & 55.8 \\
\hline & 14 years old & 24 & 31.6 & 11 & 25.6 \\
\hline & 15 years old & 1 & 2.6 & 4 & 9.3 \\
\hline & 16 years old & 0 & 0 & 1 & 2.3 \\
\hline \multirow[t]{4}{*}{3.} & Child order & & & & \\
\hline & $1^{\text {st }}$ & 7 & 18.4 & 15 & 34.9 \\
\hline & $2^{\text {nd }}-4^{\text {th }}$ & 24 & 63.2 & 26 & 60.5 \\
\hline & $5^{\text {th }}-9^{\text {th }}$ & 7 & 18.4 & 2 & 4.6 \\
\hline \multirow[t]{4}{*}{4.} & Total of siblings & & & & \\
\hline & $<2$ & 0 & 0 & 1 & 2.3 \\
\hline & $2-4$ & 26 & 68.4 & 32 & 74.4 \\
\hline & $>4$ & 12 & 31.6 & 10 & 23.3 \\
\hline
\end{tabular}

Note $: \mathrm{n}=$ number

\section{Comparison of Bullying Behaviour between Experimental and Control Group}

The difference in the mean score of bullying behaviour pre and postintervention in the intervention and control group can be seen in Table 2 . The posttest mean score in the intervention group was significantly lower than the pre-test mean $(p<.05)$ but not significantly different in the control group ( $p$ value $>.05$ ). 
Table 2. Comparison of bullying behaviour between intervention and control group

\begin{tabular}{lccccc}
\hline \multirow{2}{*}{ Group } & \multicolumn{2}{c}{ Pre-test } & \multicolumn{2}{c}{ Post-test } & \multirow{2}{*}{$\mathbf{p}$} \\
\cline { 2 - 5 } & $\mathbf{M} \pm$ SD & Min-max & M \pm SD & Min-max & \\
\hline Intervention group $(\mathrm{n}=38)$ & $28.53 \pm 6.34$ & $19-46$ & $25.47 \pm 3.93$ & $20-38$ & $<.001$ \\
Control group $(\mathrm{n}=43)$ & $30.12 \pm 6.54$ & $20-51$ & $31.65 \pm 9.28$ & $19-55$ & .17 \\
\hline
\end{tabular}

Note: $\mathrm{M} \pm \mathrm{SD}=$ mean \pm standard deviation, Min-max $=$ Minimum-Maximum

\section{DISCUSSION}

The average student in this study was a second to fourth child in a family of two to four siblings. In small families, the role of parents is more intensive and there is constant pressure to measure up to parental desires. In larger families there is less contact between parents and children, so children are often closer to each other because they do not get what they expect from their parents (Hockenberry \& Wilson, 2013).

Among adolescents, bullying risk factors can be psychological, emotional, biological and environmental (Liu \& Graves, 2011). Parental expectations and socioeconomic status have also been shown to play a role (Liu \& Graves, 2011). A large number of siblings and a lack of parental involvement is a family factor that increases the risk of bullying behaviour (Wolke \& Skew, 2012). Although a few of the children in this study did not come from particularly large families, many may have had both parents working so their parents may have been less involved with them and being in a larger city the extended family may have had a limited role in these children's lives.

A child's environment plays an important role in behaviour as they grow and develop. Parental-child attitudes and closeness are the keys that have been identified as affecting the child's ability to engage in healthy relationships at every stage of growth. Where a parent's proximity is disrupted or a child is neglected, then the child's development and personality are impacted. Exposure to physical violence is also related to bullying behavior (Liu \& Graves, 2011). The traditional culture in this part of Indonesia still relies on physical punishment of children that can lead to abuse.

Risk factors related to bullying include individual factors (ineffective communication, lack of social skills, gender, lack of empathy, and low self- esteem), environmental factors (school environment and parenting) and relationships in groups (Moura, Dias, \& Pereira, 2016).

In this research, bullying behaviour after the intervention of assertiveness skills training was low and dropped a significant $10 \%$ from before the assertiveness skill training. The number of students who were flagged as victims of bullying from the questionnaire also dropped by a smaller (7\%) but this is still a significant amount. Previous studies have shown that assertiveness skills improve the sense of awareness or assertiveness level and reduced the incidence of being bullied but not of perpetrating bullying behaviour (Avsar \& Alkaya, 2017). Assertiveness skills training can strengthen adolescent's self-awareness that they have the power to protect themselves from being bullied by others (Keliat et al., 2015). An assertiveness training program can assist students to understand the concept of assertive behaviour and how to apply it in daily life (Perron, 2013).

In this study, the steps of assertiveness skills training were straightforward communication with others, saying "no" to irrational requests, expressing complaints, rewarding others and reinforcing antibullying behaviour with socio-drama. Previous studies have used other steps to develop assertiveness behaviour in adolescents such as interpersonal skills courses, coping strategies, empathy and conflict resolution (Keliat et al., 2015).

Assertiveness skills training can help adolescents to learn how to express their opinions and their emotions without hurting others, be able to identify things from other people's points of view and learn how to interact within a group and raise sensitive issues related to the group (Paeezy, Shahraray, \& Abdi, 2010).

For effective long term bullying 
prevention within the school environment, parents, teachers and students must all be involved (Perron, 2013). Nurses also have an important role in identifying children who are the perpetrators or victims of bullying (Salmeron \& Christian, 2016) and together with teachers and other school staff, they must try to determine ways to manage them (Perron, 2013). Although teachers and support teams were satisfied with the content conveyed in class during this intervention program, many suggested that additional support was needed beyond the usual teaching schedule (Letendre \& Ostrander, 2016).

For some students in the control group, there was an increase in the bullying behaviour score and even after undergoing the assertiveness skills training there were some students in the intervention group whose bullying behaviour score still rose. This could be related to the stage of development of these early adolescents (12-14 years old).

According to Ericson's theory of psychosocial development, adolescents are at the stage where they are beginning to evaluate themselves as distinct, unique, and separate individuals. The early adolescent period begins with the onset of puberty and emotional and physical stability is generally not reached until they are almost ready to graduate from high school (Hockenberry \& Wilson, 2013). During these turbulent years, children often experience strong mood swings and struggle with both anger and low selfesteem which can increase both bullying behaviour and the characteristics that lead to vulnerability as targets of bullying.

\section{CONCLUSION AND RECOMMENDA TION}

There was a significant difference in bullying behaviour before and after the intervention of assertiveness training exercises in the intervention group, but there was no difference in bullying behaviour in the control group. Assertiveness skills training was successful in reducing bullying behaviour among these middle-school age students and could be implemented as a strategy to prevent bullying behaviour in schools. Training teachers to become assertiveness skills training facilitators and integrating it into the counseling guidance program in elementary, middle and upperlevel education should be considered.

Apart from assertiveness skills training, other interventions that can be combined are music and cognitive skills therapy. Previous studies had shown that there was a significant decrease in bullying events, and students were more relaxed when music was played. In one study bullying behaviour increased during the third week, though it remained lower than in the first week after the music was stopped. Relaxation music can be combined with assertiveness training to create a positive school atmosphere and further lessen aggressive behaviour (Ziv \& Dolev, 2013).

Nursing implications: Assertiveness training can help students to develop assertive behaviours rather than negative behaviours such as aggression and introversion, and help them to improve their social communication skills.

\section{REFERENCES}

Avsar, F., \& Alkaya, S. A. (2017). The effectiveness of assertiveness training for school-aged children on bullying and assertiveness level. Journal of Pediatric Nursing, 36, 186-190. https://doi.org/10.1016/j. pedn.2017.06.020

Beldean-galea, I. E., U, N. J. Ă., \& Igan, Ş. I. T. (2010). Frequency of bullying behaviours in secondary schools in Cluj-Napoca. Applied Medical Infromatics, 27(4), 62-66.

Boket, E. G., Bahrami, M., Kolyaie, L., \& Hosseini, S. A. (2015). The effect of assertiveness skills training on reduction of emotional victimization of female high school students. International Journal of Humanities and Cultural Studies, 690-699.

Cantone, E., Piras, A. P., Vellante, M., Preti, A., Daníelsdóttir, S., D’Aloja, E., Bhugra, D. (2015). Interventions on bullying and cyberbullying in schools: A systematic review. Clinical Practice and Epidemiology in 
Mental Health, 11, 58-76. https://doi.org/10.2174/17450179015 11010058

Center for Disease Control and Prevention, C. (2014). The relationship between bullying and suicide: What we know and what it means for schools. Chamblee: National Center for Injury and Prevention and Control, Devision of Violence Prevention. Retrieved from www.cdc.gov/violenceprevention

Evans, C. B. R., \& Smokowski, P. R. (2016). Theoretical explanations for bullying in school: How ecological processes propagate perpetration and victimization. Child Adolescen Social Work Journal, (33), 365-375. https://doi.org/10.1007/s10560-0150432-2

Ferguson, C. J., San Miguel, C., Kilburn, J. C. J., \& Sanchez, P. (2007). The effectiveness of school-based antibullying programs: A meta-analytic review. Criminal Justice Review, 32(4), 401-414. Retrieved from http://ovidsp.ovid.com/ovidweb.cgi?T $=J S \& P A G E=$ reference $\& D=p s y c 5 \& N$ $E W S=N \& A N=2008-01895-004$

Garmy, P., Vilhjálmsson, R., \& Kristjánsdóttir, G. (2018). Bullying in school-aged children in Iceland: A Cross-sectional study. Journal of Pediatric Nursing, 38, e30-e34. https://doi.org/10.1016/j.pedn.2017.0 5.009

Herman, H., Nurshal, D., \& Oktarina, E. (2017). Hubungan karakteristik remaja dengan perilaku bullying pada siswa SMP Di Kota Padang. Jurnal Keperawatan Soedirman, 12(1), 1. https://doi.org/10.20884/1. jks.2017.12.1.677

Hockenberry, M., \& Wilson, D. (2013). Wong's essentials of pediatric nursing (9 th Ed). St. Louis: Mosby Elsevier.

Horne, A. M., Stoddard, J. L., \& Bell, C. D. (2007). Group approaches to reducing aggression and bullying in school. Group Dynamics: Theory, Research, and Practice, 11(4), 262271. https://doi.org/10.1037/10892699.11.4.262

International Center for Research on Women, I. (2014). Are school safe and gender aqual space: Findings from a baseline study of school related gender based violence in five countries Asia. South Asia: Plan Internation. Retrieved from www.icwr.org.

Keliat, B. A., Tololiu, T. A., Daulima, N. H. C., \& Erawati, E. (2015). Effectiveness Assertive Training of Bullying Prevention among Adolescents in West Java Indonesia. International Journal of Nursing, 2(1), 128-134. https://doi.org/10.156 40/ijn.v2n1a14

Letendre, J., Ostrander, J. A., \& Mickens, A. (2016). Teacher and staff voices: Implementation of a positive behavior bullying prevention program in an Urban School. Children and Schools, 38(4), 237245. https://doi.org/10.1093/cs/cdw 032

Liu, J., \& Graves, N. (2011). Childhood bullying: A review of constructs, contexts, and nursing implications. Publict Health Nurs, 28(6), 556-568. https://doi.org/10.1111/j.15251446.2011.00972.x.Childhood

Moura, D. R. De, Catarina, A., Cruz, N., \& Quevedo, L. D. Á. (2011). Prevalence and characteristics of school age bullying victims. Journal of Pediatria, 87(1), 19-23. https://doi.org/10.2223/JPED.2042

Paeezy, M., Shahraray, M., \& Abdi, B. (2010). Investigating the impact of assertiveness training on assertiveness, subjective well-being and academic achievement of Iranian female secondary students. Procedia Social and Behavioral Science, 5(2), 1447-1450. https:// 
doi.org/10.1016/j.sbspro.2010.07.30 5

Parada, R. H. (2000). Adolescent Peer Relations Instrument: A theoretical and empirical basis for the measurement of participant roles in bullying and victimization of of adolescence: An interim test manual and a research monograph: $A$ test manual. Australia: Publication Unit, Self-concept Enhancement and Learning Facilitation (SELF) Research Centre.

Pepler, D., \& Craig, W. (2014). Bullying prevention and intervention in the school environment: Factsheets and tools. Atlanta, Georgia: National Center for Injury Prevention and Control Devision of Violence Prevention.

Perron, T. (2013). Peer victimisation: Strategies to decrease bullying in schools. British Journal of School Nursing, 8(1), 25-30.

Pigozi, P. L., \& Machado, A. L. (2015). Bullying during adolescence in Brazil: an overview article. Clincia
\&Saude Colectiva, 20(11), 35093523. https://doi.org/10.1590/1413812320152011.05292014

Salmeron, P. A., \& Christian, B. J. (2016). Evaluation of an educational program perceptions of bullying. Pediatric Nursing, 42(6).

Sastroasmoro, S., \& Ismail, S. (2010). Dasar-dasar Penelitian Klinis. Jakarta: Sagung Seto.

Tsitsika, A. K., Barlou, E., Andrie, E., Dimitropoulou, C., Tzavela, E. C., Janikian, M., \& Tsolia, M. (2014). Bullying behaviors in children and adolescents: " an ongoing story ." Frontiers in Public Health, 2(February), 1-4. https://doi.org/10.3389/fpubh.2014.0 0007

Wolke, D., \& Skew, A. J. (2012). Family factors, bullying victimisation and wellbeing in adolescents. Longitudinal and Life Course Studies, 3(1), 101-119. 